\title{
The Embodiment and Conditions of Labor Promoting Individuals' All-Round Development-Based on the Study of Grundrisse
}

\author{
Shanxi Zhang1,2 \\ ${ }^{1}$ School of Marxism, Southwest Jiaotong University, Chengdu, China \\ ${ }^{2}$ School of Marxism, Sichuan University of Arts and Science, Dazhou, China \\ Email: zhenshandao@163.com
}

How to cite this paper: Zhang, S. X. (2021). The Embodiment and Conditions of Labor Promoting Individuals' All-Round Development-Based on the Study of Grundrisse. Advances in Anthropology, 11, 36-43. https://doi.org/10.4236/aa.2021.111004

Received: January 18, 2021

Accepted: February 20, 2021

Published: February 23, 2021

Copyright $\odot 2021$ by author(s) and Scientific Research Publishing Inc. This work is licensed under the Creative Commons Attribution International License (CC BY 4.0).

http://creativecommons.org/licenses/by/4.0/

\section{(c) (i) Open Access}

\begin{abstract}
Realizing individuals' all-round development is the fundamental value goal pursued by Marxism. There is an internal unity between labor and individuals' all-round development. Productive labor can promote the overall development of individuals' mental and physical strength, and attractive labor with the characteristics of autonomy, innovation and seriousness can promote the development of human-being's free individuality. It needs certain conditions for labor to promote individuals' all-round development. As far as labor practice itself is concerned, happy labor, scientific labor, efficient labor and cooperative labor are the necessary conditions for labor to promote individuals' all-round development.
\end{abstract}

\section{Keywords}

Labor, Individuals' All-Round Development, Attractive Labor, Embody, Conditions, Grundrisse

\section{Introduction}

At present, some people, especially teenagers, have a weak sense of labor, love leisure but hate work, "NEET" and "giant baby" phenomenon is common; some laborers are satisfied with the existing state of affairs and reluctant to move forward, slackness, procrastination, inaction and other inefficient labor phenomenon is outstanding; some people take advantage of opportunism, break through moral and legal bottom line with cheating, manufacturing and selling faked goods, plagiarism and so on. Why does the phenomenon of neglecting or even 
disdaining labor happen? One reason is that affected by the utilitarian social environment, the negative effect of the Internet, the lack of labor education and other factors, some people set labor against individuals' development, and do not really realize that labor can promote individuals' development. The other reason is that because the necessary conditions for labor to promote individuals' development widely are not yet mature, "there are a lot of alienated labors in the real world" (Yu, 2007). Therefore, the research on the relationship between labor and individuals' development has a positive guiding significance for reshaping people's labor view and promoting individuals' all-round development. Based on the interpretation of Marx's "Grundrisse: Foundations of the critique of political economy" (hereinafter referred to as the "Grundrisse"), this paper will analyze the embodiment and conditions of labor promoting individuals' all-round development.

\section{Embodiment of Labor Promoting Individuals' All-Round Development}

Realizing individuals' all-round development is the fundamental value goal pursued by Marxism. Individuals' all-round development means that human-being's "physical strength and intelligence are fully and freely developed and utilized" (Bureau of Compilation and Translation of Works of Marx, Engels, Lenin and Stalin, 2012b: p. 670). It can be seen that the individuals' all-round development includes the all-round development of mental and physical strength and the development of free individuality. Grundrisse discusses the relationship between labor and the two aspects of individuals' all-round development.

\subsection{Influence of Labor on the Overall Development of Individuals' Mental and Physical Strength}

Marx believed that labor creates wealth, and wealth "is the universality of individual needs, talents, enjoyment, productivity and so on which is produced in the universal exchange" (Bureau of Compilation and Translation of Works of Marx, Engels, Lenin and Stalin, 1995: p. 479). Therefore, labor can lay a material foundation for individuals' all-round development. When labor exceeds the limits of individuals' natural needs, it can also "create material elements for the development of rich individuality, which is overall both in production and consumption." (Bureau of Compilation and Translation of Works of Marx, Engels, Lenin and Stalin, 1995: p. 286)

Not only that, Marx also believed that productive labor can directly promote the overall development of individuals' mental and physical strength. In the Grundrisse, he pointed out that "for growing people, this direct production process is training at the same time, while for adults who have accumulated social knowledge in their minds, this process is [knowledge] application, experimental science, material creativity and objectification science. For these two kinds of people, as long as labor requires hands-on and free activities, as in agriculture, this process is also physical exercise." (Bureau of Compilation and 
Translation of Works of Marx, Engels, Lenin and Stalin, 1998: p. 108)

The premise of the above analysis is to divide individuals into "growing people" and "adults with accumulated social knowledge". On the one hand, Marx pointed out that labor can promote the development of individuals' mental strength. However, for the two kinds of people, the specific situation of promoting mental development is different. For "growing people", labor "is training", that is, it can make them increase knowledge and cultivate skills. For "adults with accumulated social knowledge", labor is "the application of knowledge, experimental science, material creativity and objectification science", that is, it can consolidate their knowledge and facilitate the innovation of knowledge. On the other hand, Marx pointed out that labor can promote the development of individuals' physical strength. In this respect, the labor effect of the two kinds of people is the same, that is, as long as "hands-on and free activities, this process is physical exercise at the same time". Of course, the labor of "promoting individuals' physical development" discussed by Marx specifically refers to "productive labor", and pure mental labor obviously cannot promote the development of individuals' physical strength.

\subsection{Influence of Labor on the Development of Human-Being's Free Individuality}

Before Marx, Adam Smith set labor completely against freedom, and thought that labor meant sacrificing "comfort, freedom and happiness". On the other hand, Fourier demonstrated the unity of labor and freedom. "Everyone is born to love a certain kind of labor... The essence of human spirit lies in making ourselves active and promoting physical activities. Therefore, there is no need to force people to act as they do in today's social situation, as long as we give correct guidance to people's inherent activities needs." "Under a reasonable system, when everyone can work according to their own interests, labor can restore its true colors and become a kind of enjoyment." (Bureau of Compilation and Translation of Works of Marx, Engels, Lenin and Stalin, 2002: p. 478)

In the Grundrisse, Marx not only refuted Adam Smith's viewpoint, but also critically inherited Fourier's theory of free labor. He first pointed out that under normal circumstances, people "have the need to engage in a normal job and stop being comfortable ... Overcoming this obstacle itself is the realization of freedom ... and this kind of freedom which can be seen in activities is exactly labor." (Bureau of Compilation and Translation of Works of Marx, Engels, Lenin and Stalin, 1995: p. 615) Next, he made a dialectical analysis on whether labor can promote the development of free individuality. He divided labor into forced labor and attractive labor. Forced labor is the labor dominated by inevitability and external purpose, such as slave labor, corvee labor and employment labor. For the laborer, forced labor "belongs to himself, but it is alien and forced life activity for him" (Bureau of Compilation and Translation of Works of Marx, Engels, Lenin and Stalin, 1995: p. 464), so it is always a disgusting thing and cannot promote the development of human-being's free individuality. On the contrary, 
non-labor is freedom and happiness.

Attractive labor is the labor which is free from the domination of inevitability and external purpose, such as the labor of artists and scholars. Attractive labor has three characteristics: first, attractive labor has autonomy or freedom, which is its most essential characteristic. Autonomy shows that attractive labor gets rid of the dependence on people and things, and reflects the self needs and wishes of laborers. "It is regarded as the purpose put forward by individuals themselves, so it is regarded as self-realization, the objectification of the subject, that is to say the real freedom." (Bureau of Compilation and Translation of Works of Marx, Engels, Lenin and Stalin, 1995: p. 615) Secondly, attractive labor has innovativeness. It is "active and creative activity" (Bureau of Compilation and Translation of Works of Marx, Engels, Lenin and Stalin, 1995: p. 618). This is the internal reason why attractive labor attracts people. Generally speaking, new forms of labor are more likely to stimulate people's interest and bring happiness, so they are more attractive. Innovative or creative labor achievements can stimulate people's interest, sense of achievement and honor, so they can attract people more deeply. Thirdly, attractive labor has seriousness, which reflects the labor attitude of attractive labor. Attractive labor is not entertainment. "Real free labor, such as composing music, is also a very serious and intense thing." (Bureau of Compilation and Translation of Works of Marx, Engels, Lenin and Stalin, 1995: p. 616) Seriousness means that attractive labor is consistent with focused labor, hard labor and honest labor. The above characteristics determine the unity of attractive labor and human-being's free individuality. Attractive labor is closely related to individuals' needs and interests. Engaging in attractive labor can promote the development of human-being's free individuality, and even means individuals' self-realization.

\section{Conditions for Labor to Promote Individuals' All-Round Development}

It needs certain conditions for labor to promote individuals' all-round development. According to the relevant discussion about the labor practice in Grundrisse, Interest in labor, scientificalness of labor, efficiency of labor, relationship among laborers are the important factors that restrict whether labor can promote individuals' all-round development.

\subsection{Interest in Labor}

Interest is an important condition for labor to promote individuals' all-round development. If we only regard labor as a kind of responsibility and obligation, and have no interest in it, then this kind of labor is more like what Marx called "forced labor", which is completely different from the development of human-being's free individuality, and it is difficult to effectively stimulate the creative potential of laborers. The labor consistent with interest is happy labor, which can effectively promote individuals' all-round development. Firstly, happy 
labor based on interest promotes the development of human-being's free individuality. Only when labor is organically combined with interests and hobbies, can labor become "attractive labor" which is consistent with the internal needs and wishes of laborers, and promote the development of human-being's free individuality. Secondly, happy labor based on interest promotes the development of individual creativity and other aspects. When labor becomes a kind of happiness based on interest, it will greatly mobilize the enthusiasm of laborers and stimulate their strong subjective consciousness, "then the imagination and creativity hidden in everyone's body can be brought into full play." (Yu, 2007) The exertion of this potential is not only the performance of individual creativity development, but also can greatly improve the labor efficiency, so as to create spare time for the development of other aspects of laborers.

\subsection{Scientificalness of Labor}

Forced labor, which deviates from human-being's free individuality, mainly refers to hard, tedious and direct low-level physical labor. The truly free "labor has scientificalness" (Bureau of Compilation and Translation of Works of Marx, Engels, Lenin and Stalin, 1995: p. 616). Scientific labor is the advanced labor with scientific knowledge, which is consistent with human-being's free individuality and can promote individuals' all-round development. Taking the technology of automated factory as an example, Marx pointed out that scientific labor "is no longer shown that it is included in the production process as before, on the contrary, it is shown that human being has a relationship with the production process itself as the supervisor and regulator of the production process... In this transformation ... which is shown as the grand cornerstone of production and wealth ... is human-being's understanding of nature and his dominion over the natural world through human-being's existence as a social entity. In short, it is the development of social individuals." (Bureau of Compilation and Translation of Works of Marx, Engels, Lenin and Stalin, 1998: pp. 100-101) Nowadays, human beings have entered the era of knowledge innovation. Knowledge innovation labor with strong scientificalness is not only a free exploration and creation activity to satisfy people's curiosity and serve people's self-improvement, but also an activity to show and enrich individuals' mental and physical strength. It is an important way to promote individuals' all-round development (Lou, 2006). The premise of scientific labor is that social members are familiar with science. Therefore, Marx expected that in the foreseeable future, the science education that is still enjoyed by the privileged minority in the society can be popularized to everyone. As for the specific path of science education, Marx advocated the combination of education and productive labor in Capital, "For all children who have reached a certain age, future education is the combination of productive labor with intellectual education and physical education. It is not only a way to improve social production, but also the only way to bring up human being with all-round development." (Marx, 2018: pp. 556-557) 


\subsection{Efficiency of Labor}

The overall development of individuals' physical and mental strength is closely related to consumption, and the improvement of consumption level depends on the development of productivity, which is based on the improvement of labor efficiency. The standard of measuring labor efficiency is the amount of necessary labor time. The less time, the higher efficiency. As Marx said in the Grundrisse, "the real economy-saving-is the saving of labor time. And the saving is equal to developing productivity... Therefore, it not only develops the consumption capacity, but also develops consumption goods. The consumption capacity ... is a kind of development of individuals' talent." (Bureau of Compilation and Translation of Works of Marx, Engels, Lenin and Stalin, 1998: pp. 107-108)

Promoting the development of human-being's free individuality is inseparable from the free time of leisure. The way to increase free time is to shorten the working day. The shortening of working days means saving labor time. Reducing the necessary labor time "frees up time and creates means for all people, so individuals will develop in art, science and so on." (Bureau of Compilation and Translation of Works of Marx, Engels, Lenin and Stalin, 1998: pp. 100-101) There is no doubt that to save labor time, we must improve labor efficiency. "Labor productivity is determined by a variety of conditions, including the average proficiency of workers, the level of science development and its application in technology, the social integration of production process, the scale and efficiency of means of production, and natural conditions." (Marx, 2018: p. 53) It can be seen that improving labor efficiency requires both subjective and objective conditions. From the objective aspects, efficient labor is inseparable from the support of science and technology, moderate scale production, good natural conditions and so on. From the subjective aspects, efficient labor needs to improve the skill level of laborers. In addition, laborers should also establish the concept of efficiency first, take the initiative in work, cherish and save time like life, constantly improve labor productivity, and win time for individuals' all-round development.

\subsection{Relationship among Laborers}

Marx believed that "human nature is not an abstract thing inherent in a single person. In its reality, it is the sum of all social relations." (Bureau of Compilation and Translation of Works of Marx, Engels, Lenin and Stalin, 2012a: p. 139) Therefore, the individual is inseparable from the society, and individuals' all-round development is based on the harmonious social relations. The abnormal development of private ownership and social division of labor leads to the alienation of the interpersonal relationship. Therefore, Marx pointed out in the Grundrisse that the truly free labor is the cooperative labor which eliminates the division of mental labor and physical labor. The "labor has sociality" (Bureau of Compilation and Translation of Works of Marx, Engels, Lenin and Stalin, 1995: p. 616), which eliminates the social phenomenon of the alienation of interper- 
sonal relationship and makes everyone "satisfied in spontaneous intellectual activities. The satisfaction here comes not only from the activity itself, but also from the unity among producers." (Musto, 2016) For the cooperative labor which is consistent with the development of human-being's free individuality, Marx took the symphony orchestra as an example to describe it in detail. In an orchestra with tacit cooperation, each musician is a relatively independent individual, and at the same time, he regards himself as a part of the whole-the co-performer of the symphony.

\section{Conclusion}

Based on the relevant analysis of Marx's labor view, we can draw the following two conclusions:

Firstly, labor and individuals' all-round development are internally unified. Productive labor can promote the overall development of individuals' mental and physical strength, and attractive labor can promote the development of human-being's free individuality. The conclusion has the following enlightenment: in the new era of socialism with Chinese characteristics, the propaganda and ideological work front and labor education institutions can reshape people's labor view according to Marx's labor view, guide people to truly realize the significance of labor for social progress and individuals' all-round development, and make people understand that labor is the most glorious, most noble, greatest and most beautiful, so as to enhance the consciousness of initiative labor, hard work, honest work and creative work. When employers organize people to work or schools carry out labor practice education for students, they should, as far as possible, according to the actual needs of laborers, take autonomy and innovation as the guidance, and expand new attractive labor practice forms.

Secondly, labor needs certain conditions to promote individuals' all-round development, and not all labor can promote individuals' all-round development. Happy labor, scientific labor, efficient labor and cooperative labor are the necessary conditions for labor to promote individuals' all-round development. The conclusion has the following enlightenment: individuals should choose jobs based on their interests as far as possible and cultivate their feelings for labor. Education should not guide and encourage students to pursue popular occupations, but should stimulate them to find the occupations they are really interested in as soon as possible. Government, enterprises and schools should focus on vocational skills training and science and technology education, and constantly improve people's labor skills and labor creativity, which can not only provide more leisure time for people through labor productivity, but also benefit the development of human-being's free individuality. Families, schools and society should guide people to realize that efficient labor and cooperative labor are the necessary conditions to promote individuals' all-round development, so as to consciously resist idleness, sloppiness, bombast, procrastination and other inefficient labor phenomena, and enhance the sense of cooperation in labor. 


\section{Founding}

This article is one of the achievements of the project of Research Center for the Development of Sichuan Old Revolutionary Base Areas in 2019. The project is "Reshaping people's labor view in the targeted poverty alleviation of Sichuan old revolutionary base areas" (SLQ2019B-08).

\section{Conflicts of Interest}

The author declares no conflicts of interest regarding the publication of this paper.

\section{References}

Bureau of Compilation and Translation of Works of Marx, Engels, Lenin and Stalin (1995). Complete Works of Max and Angles (Volume 30). Beijing: People's Publishing House.

Bureau of Compilation and Translation of Works of Marx, Engels, Lenin and Stalin (1998). Complete Works of Max and Angles (Volume 31). Beijing: People's Publishing House.

Bureau of Compilation and Translation of Works of Marx, Engels, Lenin and Stalin (2002). Complete Works of Max and Angles (Volume 3). Beijing: People's Publishing House.

Bureau of Compilation and Translation of Works of Marx, Engels, Lenin and Stalin (2012a). Selected Works of Marx and Engels (Volume 1). Beijing: People's Publishing House.

Bureau of Compilation and Translation of Works of Marx, Engels, Lenin and Stalin (2012b). Selected Works of Marx and Engels (Volume 3). Beijing: People's Publishing House.

Lou, H. X (2006). Knowledge Innovation Labor: A Realistic Possibility of Individuals' All-Round and Free Development. The Journal of Humanities, 1, 28.

Marx, K. (2018). Capital (Volume 1). Beijing: People's Publishing House.

Musto, M. (2016). Karl Marx's Grundrisse: Foundations of the Political Economy 150 Years Late (p. 161). Beijing: China Renmin University Press.

Yu, Z. P. (2007). Labor: Existence Way of Being Human-From Criticism of Modernity to Vision of Postmodernism. Tianjin Social Sciences, 6, 4-7. 